\title{
Hubungan Antara Servant Leadership Dengan Komitmen Organisasi Pada Karyawan Rumah Sakit Delta Surya Sidoarjo
}

\author{
Fachreza Abhitama Akbar dan Olievia Prabandini Mulyana ${ }^{1}$ \\ Program Studi Psikologi Universitas Negeri Surabaya
}

\begin{abstract}
Hospital is an integral part of social and health organization that function is to provide health services to people. The background of this study was an existing problem in regard to organization commitment among employees in Delta Surya Hospital. The purpose of this study was to investigate the relationship between servant leadership with organization commitment to employees delta surya hospital sidoarjo. The variables which were examined in this study were servant leadership as the independent variable and organization commitment as the dependent variable. This study was a quantitative research, involving 32 employeesas research subject which were selected by purposive sampling out of 386 employees of total population. The data collecting instruments used were the servant leadership and organization commitment scale. Data analysis method used was product moment correlation. The result of the data had showen a correlation coefficient value of $0,617(r=0,617)$ with significance level of 0,004 $(p=0,004)$. This result indicated that there was a relationship between servant leadership and organization commitment. Thus, the higher the servant leadership among employees are, the better the organization commitment would be, and vice versa.
\end{abstract}

Keywords: Servant Leadership and Organizational Commitment.

\begin{abstract}
Abstrak: Rumah sakit adalah bagian integral dari suatu organisasi sosial dan kesehatan dengan fungsi menyediakan pelayanan kesehatan bagi masyarakat. Latar belakang penelitian ini adalah adanya masalah komitmen organisasi yang terjadi pada karyawan. Tujuan dari penelitian ini adalah untuk mengetahui apakah terdapat hubungan antara servant leadership dengan komitmen organisasi pada karyawan Rumah Sakit Delta Surya Sidoarjo. Variabel yang dikaji pada penelitian ini adalah variabel servant leadership sebagai variabel bebas dan variabel komitmen organisasi sebagai variabel terikat. Penelitian ini menggunakan metode kuantitatif, dengan subjek penelitian berjumlah 32 karyawan dari jumlah populasi 386. Pengambilan sampel dilakukan dengan teknik purposive sampling. Instrumen penelitian yang digunakan adalah skala servant leadership dan skala komitmen organisasi. Skala disusun menggunakan pemodelan skala likert. Metode analisis data menggunakan korelasi product moment untuk menguji hubungan antara dua variabel, yaitu servant leadership dan komitmen organisasi.Hasil analisis data menunjukkan nilai koefisien korelasi sebesar 0,617 $(\mathrm{r}=0,617)$ dengan taraf signifikansi $0,004(\mathrm{p}=0,004)$. Hasil tersebut menunjukkan bahwa terdapat hubungan antara servant leadership dengan komitmen organisasi. Semakin tinggi servant leadership karyawan, maka semakin baik komitmen organisasinya, begitu pula sebaliknya.
\end{abstract}

Kata kunci: Servant Leadership dan Komitmen Organisasi.

Rumah sakit adalah organisasi yang unik dan kompleks karena ia merupakan institusi yang padat karya, mempunyai sifat- sifat dan ciri-ciri serta fungsi-fungsi yang khusus dalam proses menghasilkan jasa medik dan mempunyai berbagai kelompok

\footnotetext{
${ }^{1)}$ Korespondensi tentang artikel ini dapat dialamatkan kepada Fachreza Abhitama Akbar melalui e-mail: fachrezahrd@yahoo.com.
} 
profesi dalam pelayanan penderita. Mengingat adanya dinamika internal (perkembangan peran) dan tuntutan eksternal yang semakin berkembang, rumah sakit dihadapkan pada upaya penyesuaian diri untuk merespon dinamika eksternal dan fungsi integrasi potensi internal dalam melaksanakan tugas yang semakin kompleks.Dinamika internal dan tuntutan eksternal menyebabkan rumah sakit didalam melaksanakan fungsinya sebagai penyedia jasa pelayanan kesehatan masyarakat dituntut untuk mampu mengatasi permasalahan yang ada.

Permasalahan yang sering dihadapi oleh rumah sakit agar mencapai keberhasilan adalah masalah antara sumber daya manusia dengan organisasi, yang berkaitan dengan tuntutan-tuntutan baik dari organisasi maupun sumber daya manusia itu sendiri.Rumah sakit sebagai institusi padat karya tidak terlepas dari berbagai persoalan.Dengan karakteristik rumah sakit yang seperti itu, tentu saja dibutuhkan kepemimpinan yang berbeda dengan kepemimpinan pada organisasi lainnya yang dapat berpengaruh pada komitmen organisasi perusahaannya.

Fenomena yang berkembang dalam dunia industri dan organisasi adalah para profesional cenderung lebih berkomitmen terhadap profesi daripada perusahaan tempatnya bekerja. Karyawan yang berkomitmen terhadap profesi tidak selalu merujuk pada suatu organisasi, sehingga karyawan seperti ini selalu berpindah-pindah kerja ke tempat lain (Fineman, dkk., 2005). Fenomena tersebut salah satunya disebabkan oleh adanya kesenjangan antara karyawan yang bekerja disatu perusahaan dengan karyawan yang bekerja di tempat lain, walaupun mereka memiliki deskripsi pekerjaan yang sama.

Berangkat dari kenyataan tersebut di atas maka pengelolaan dan pengembangan sumber daya manusia dalam organisasi atau perusahaan merupakan suatu keharusan dan tidak bisa ditawar-tawar lagi, mengingat peran sumber daya manusia saat ini telah mengalami pergeseran yang sangat signifikan. Persaingan perusahaan yang ketat ini membutuhkan manajemen puncak yang dapat mengadaptasi semua persaingan tersebut menjadi suatu peluang usaha yang mampu mempertahankan perusahaan. Seorang pemimpin yang mampu mentransformasi perubahan dan persaingan usaha serta didukung oleh karyawan yang memiliki komitmen organisasi yang tinggi dan untuk mendukung pemimpinnya dalam mencapai tujuan perusahaan merupakan salah satu jalan untuk mengatasi persaingan dan permasalahan tersebut.

Menurut Turner, kepemimpinan yang tepat untuk dapat mewujudkan semua itu adalah kepemimpinan yang mampu memberikan pelayanan bagi anggotanya, institusi dimana dia bekerja dan juga masyarakat di sekitar tempat dia bekerja. Seorang pemimpin sejatinya adalah seorang pelayan (Lantu, 2007). Sebuah model kepemimpinan baru, yaitu model kepemimpinan yang mencoba untuk secara simultan meningkatkan pertumbuhan personal dari para pekerja dan memperbaiki kualitas pelayanan dari organisasi melalui kombinasi atas kerjasama tim dan pengembangan komunitas, keterlibatan personal dalam proses pembuatan keputusan serta perilaku yang peduli dan etis. Pendekatan yang baru muncul dalam konsep kepemimpinan ini kemudian disebut dengan kepemimpinan pelayan - servant leadership (Lantu, 2007).

Servant leadership adalah sebuah konsep kepemimpinan etis yang diperkenalkan oleh Robert K. Greenleaf pada tahun 1970 (Lantu, 2007). Greenleaf menghabiskan 40 tahun kariernya di bidang penelitian manajemen, pengembangan, dan pendidikan pada perusahaan AT\&T. Model 
servant leadership ini esensinya adalah melayani orang lain, yaitu pelayanan kepada karyawan, pelanggan, dan masyarakat, sebagai prioritas utama dan yang pertama. Greenleaf dalam bukunya yang berjudul servant leadership menyebutkan, servant leadership adalah suatu kepemimpinan yang berawal dari perasaan tulus yang timbul dari dalam hati yang berkehendak untuk melayani, yaitu untuk menjadi pihak pertama yang melayani.

Karakteristik utama yang membedakan antara servant leadership dengan kepemimpinan lainnya adalah keinginan untuk melayani hadir sebelum adanya keinginan untuk memimpin. Hal ini terjadi sebagai bagian dari pemenuhan misi hidup seseorang, yaitu bagaimana memberikan sesuatu yang positif untuk dunia ini dalam upaya menciptakan dunia yang lebih baik. Sebagai konsekuensinya, kemudian ia dipilih oleh para pengikutnya dan diminta untuk memimpin mereka.

Para peneliti mengungkapkan bahwa servant leadership merupakan teori konseptual yang valid untuk mengembangkan organisasi yang sehat. Greenleaf (1977) meneliti servant leadership di berbagai macam organisasi seperti bisnis, yayasan dan lain - lain. Jim Laub (2004) mendefinisikan servant leadership yaitu sebagai "sebuah pemahaman dan praktek kepemimpinan yang lebih mengutamakan pengembangan pengikutnya dibandingkan kepentingan pribadi sang pemimpin"

Greenleaf (1970, dalam Anderson, 2008 ) menggambarkan filosofi kepemimpinan baru yang disebut servant leadership. Graham (1991) melihat servant leadership sebagai salah satu bentuk kepemimpinan karismatik yang paling besar dipengaruhi oleh moral, yang ditunjukkan oleh karakteristik terpentingnya berupa humility, relational power, autonomy, moral development of followers, dan emulation of leader's service orientation. Sementara itu, spears (1995) memperluas greenleaf dengan mengajukan 10 karakteristik servant leader, yaitu listening, empathy, healing, awareness, persuasion, conseptualization foresight, stewardship, commitment to the growth of people, dan community building. Barbuto dan Wheeler (2006) menambahkan karakteristik calling pada 10 karakteristik dari spears tersebut sehingga menjadi 11 karakteristik kepemimpinan. Analisis faktor dalam penelitian Barbuto dan Wheeler (2006) menghasilkan 5 faktor, yaitu altruistic calling, emotional healing, wisdom, persuasive mapping, dan organizational stewardship.

Berdasarkan hasil studi tersebut, Barbuto dan Wheeler mengajukan 8 karakteristik utama seorang servant leadership sebagai berikut: Altruistic calling menggambarkan hasrat yang kuat dari pemimpin untuk membuat perbedaan positif pada kehidupan orang lain dan meletakkan kepentingan orang lain diatas kepentingannya sendiri dan akan bekerja keras untuk memenuhi kebutuhan bawahannya.

Emotional healing menggambarkan komitmen seorang pemimpin dan keterampilannya untuk meningkatkan dan mengembalikan semangat bawahan dari trauma atau penderitaan.

Wisdom menggambarkan pemimpin yang mudah untuk menangkap tanda-tanda di lingkungannya, sehingga memahami situasi dan memahami implikasi dari situasi tersebut.

Persuasive mapping menggambarkan sejauhmana pemimpin memiliki keterampilan untuk memetakan persoalan dan mengkonseptualisasikan kemungkinan tertinggi untuk terjadinya dan mendesak seseorang untuk melakukan sesuatu ketika mengartikulasikan peluang.

Organizational stewardships menggambarkan sejauh mana pemimpin menyiapkan organisasi untuk membuat kontribusi positif terhadap lingkungannya 
melalui program pengabdian masyarakat dan pengembangan komunitas dan mendorong pendidikan tinggi sebagai satu komunitas.

Humility menggambarkan kerendahan hati pemimpin, serta menempatkan dan menghargai prestasi orang lain lebih dari prestasinya sendiri.

Vision menggambarkan sejauh mana pemimpin mencari komitmen suatu anggota organisasi terhadap sisi bersama dengan mengajak anggota untuk menentukan arah masa depan organisasi dan menuliskan visi bersama.

Service menggambarkan sejauh mana pelayanan dipandang sebagai inti dari kepemimpinan dan pemimpin menunjukkan perilaku pelayanannya kepada bawahan.

Banyak ahli yang mencoba membandingkan servant leadership dengan bentuk kepemimpinan yang lain. Bass (2000) dalam diskusinya tentang transformational leadership dengan bentuk kepemimpinan yang lain menyatakan bahwa terdapat banyak kesamaan servant leadership dengan transformational leadership. Kesamaan tersebut terkait dengan karakteristik vision, influence, credibility, trust, dan service. Namun, servant leadership mempunyai tingkat yang lebih tinggi dari transformational leadership karena terdapat penyamaan (alignment) motif pemimpin dan bawahan. Servant leadership memiliki kesamaan prinsip dengan teori LMX (LeaderMember Xchange) yang yang dikemukakan oleh Barbuto dan Wheeler (2006). Pada teori LMX, pemimpin dengan LMX yang tinggi mengembangkan trusting dan mutually beneficial relationship with employees sama seperti servant leader yang mengembangkan strong supportive relationship with all employees and colleagues (Greenleaf, 1996, dalam Spears, 2005).

Fokus utama dari servant leadership adalah pada bagaimana mengembangkan pihak lain (pengikut, komunitas internal dan eksternal), bukan untuk mementingkan diri sendiri. Pemenuhan kepentingan diri sendiri bukanlah hal yang dicari oleh seorang servant leadership, tetapi lebih pada tingkatan pencarian motivasi yang lebih tinggi (Greenleaf, 1996).

Tujuan utama dari seorang servant leadership adalah melayani dan memenuhi kebutuhan pihak lain, yang secara optimal seharusnya menjadi motivasi utama kepemimpinan (Russel \& Stone, 2002). Servant leadershipakan mengembangkan setiap individu di sekitarnya, membantu individu agar berhasil dalam kehidupan dan juga dalam pekerjaan.

Berdasarkan penjelasan tersebut tampak jelas bahwa dengan memprioritaskan pengembangan, karyawan sebagai hal yang utama dan pertama, secara tidak langsung pemimpin mengarahkan perusahaan menuju keberhasilan jangka panjang atau sesuatu yang sifatnya dapat berlangsung secara berkesinambungan (sustainability). Hal ini tentunya diharapkan dapat meningkatkan komitmen karyawan terhadap organisasi.

Menurut Mathias dan Jackson dalam Sopiah (2008), komitmen organisasi adalah derajat kepercayaan karyawan dan penerimaan terhadap tujuan-tujuan organisasi yang akan mempengaruhi keputusannya untuk tetap tinggal atau tidak (meninggalkan organisasi). Mowday dalam Sopiah (2008) menyebutkan bahwa komitmen kerja adalah istilah lain dari komitmen organisasional. Komitmen organisasional merupakan dimensi perilaku penting yang dapat digunakan untuk menilai kecenderungan karyawan untuk bertahan sebagai anggota organisasi. Komitmen organisasional merupakan identifikasi dan keterlibatan seseorang yang relatif kuat terhadap organisasi. Komitmen organisasional adalah keinginan anggota organisasi untuk mempertahankan keanggotaannya dalam organisasi dan bersedia berusaha keras bagi 
pencapaian tujuan organisasi.

Lebih lanjut lagi, Lincoln dalam Sopiah, (2008) menyebutkan bahwa komitmen organisasional mencakup kebanggaan anggota, kesetiaan anggota, dan kemauan anggota pada organisasi. Blau dan Boal(dalam Sopiah, 2008) menyatakan bahwa komitmen organisasional didefinisikan sebagai suatu sikap yang merefleksikan perasaan suka atau tidak suka dari karyawan terhadap organisasi.

Keberhasilan pengelolaan organisasi sangatlah ditentukan oleh keberhasilan dalam mengelola SDM. Dalam studi manajemen sumber daya manusia, komitmen organisasional sebagai salah satu aspek yang mempengaruhi perilaku manusia dalam organisasi telah menjadi hal penting yang telah banyak didiskusikan dan diteliti. Alasannya sangat sederhana, contohnya sebaik apapun visi, misi, dan tujuan organisasi, tidak akan tercapai jika tidak ada komitmen dari anggota organisasinya.

Beberapa definisi yang disebutkan dapat disimpulkan bahwa komitmen organisasi adalah suatu ikatan psikologis karyawan pada organisasi yang ditandai dengan adanya kepercayaan dan penerimaan terhadap tujuan-tujuan dan nilai-nilai dari organisasi, kemauan untuk menggunakan usaha yang sungguh-sungguh guna kepentingan organisasi, serta keinginan untuk memelihara keanggotaan dalam organisasi.

Kanter dalam Sopiah (2008), mengemukakan adanya tiga bentuk komitmen organisasional, yaitu (1) komitmen berkesinambungan (continuance commitment), yaitu komitmen yang berhubungan dengan dedikasi anggota dalam melangsungkan kehidupan organisasi dan menghasilkan orang yang mau berkorban dan berinvestasi pada organisasi; (2) komitmen terpadu (cohesion commitment), yaitu komitmen anggota terhadap organisasi akibat adanya hubungan sosial dengan anggota lain di dalam organisasi. Ini terjadi karena karyawan percaya bahwa norma-norma yang dianut organisasi. Ini terjadi karena karyawan percaya bahwa norma-norma yang dianut organisasi merupakan norma-norma yang bermanfaat; dan (3) komitmen terkontrol (control commitment), yaitu komitmen anggota pada norma anggota organisasi yang memberikan perilaku yang diinginkannya. Norma yang dimiliki organisasi mampu memberikan sumbangan terhadap perilaku yang diinginkannya.

Selanjutnya menurut Meyer, Allen, dan Smith dalam Sopiah (2008) ada tiga komponen komitmen organisasional, yaitu (1) affective commitment, terjadi apabila karyawan ingin menjadi bagian dari organisasi karena adanya ikatan emosional; (2) Continuance commitment, muncul apabila karyawan tetap bertahan pada suatu organisasi karena membutuhkan gaji dan keuntungan lain, atau karena tidak menemukan pekerjaan lain; dan (3) Normative commitment, timbul dari nilai-nilai dalam diri karyawan. Karyawan bertahan menjadi anggota organisasi karena adanya kesadaran bahwa komitmen terhadap organisasi merupakan hal yang seharusnya dilakukan.

Komitmen organisasi terbangun bila tiap individu mengembangkan tiga sikap yang saling berhubungan terhadap organisasi dan atau profesi meliputi identification yaitu pemahaman atau penghayatan dari tujuan organisasi, involvement yaitu perasaan terlibat dalam suatu pekerjaan atau perasaan bahwa pekerjaannya adalah menyenangkan, dan loyality yaitu perasaan bahwa organisasi adalah tempat bekerja dan tinggal.

Menurut David dalam Sopiah, (2008) mengemukakan empat faktor yang mempengaruhi komitmen karyawan pada organisasi, yaitu faktor personal, misalnya usia, jenis kelamin, tingkat pendidikan, pengalaman kerja, kepribadian; karakteristik pekerjaan, misalnya lingkup jabatan, 
tantangan, konflik peran, tingkat kesulitan dalam pekerjaan; karakteristik struktur, misalnya besar/kecilnya organisasi, bentuk organisasi (sentralisasi/desentralisasi), kehadiran serikat pekerja; dan pengalaman kerja. Faktor pengalaman kerja sangat berpengaruh terhadap tingkat komitmen karyawan pada organisasi. Karyawan yang baru beberapa tahun bekerja dan karyawan yang sudah puluhan tahun bekerja tentu memiliki tingkat komitmen yang berlainan dalam organiasi.

Dengan demikian, dapat disimpulkan bahwa pengelolaan sumber daya manusia yang tepat di dalam organisasi dapat mempengaruhi keberhasilan dalam meningkatkan pendapatan dan profit perusahaan terus-menerus. Hal ini tidak terkecuali bagi Rumah Sakit (RS) Delta Surya Sidoarjo. RS ini adalah rumah sakit swasta yang ada di Kabupaten Sidoarjo. Sebagai rumah sakit swasta, RS Delta Surya Sidoarjo dapat dikategorikan sebagai organisasi penyedia jasa yang mengandalkan kualitas pelayanan jasa yang diberikan kepada masyarakat.

RS ini pada awalnya hanya memiliki lima pelayanan kesehatan, yang meliputi administrasi, pelayanan medis, pelayanan gawat darurat, keperawatan, rekam medis. Namun, pada tahun 2002 RS Delta Surya memiliki 12 pelayanan kesehatan yang meliputi administrasi, pelayanan medis, pelayanan gawat darurat, keperawatan, rekam medis, farmasi, radiologi, K3, laboratorium, $\mathrm{OK}, \mathrm{ICU}$, dalin, perinatal resiko tinggi. RS Delta Surya merupakan rumah sakit swasta tipe B di kabupaten Sidoarjo (Anonim, 2008).

Permasalahan yang ada dalam RS Delta Surya berupa tindakan-tindakan dari karyawan yang berdampak kurang baik bagi rumah sakit, seperti karyawan yang datang terlambat dan pulang sebelum jam kerja selesai sehingga kinerja yang diharapkan kurang sesuai dengan pelaksanaannya, banyaknya karyawan yang belum mengetahui visi dan misi RS Delta Surya Sidoarjo dan hal ini dapat menghambat rumah sakit dalam pencapaian visi dan misi tersebut.

Berdasarkan uraian di atas, maka peneliti tertarik untuk mengetahui apakah terdapat hubungan antaraservant leadership dengan komitmen organisasi pada karyawan Rumah Sakit Delta Surya Sidoarjo.

\section{METODE}

Penelitian ini menggunakan pendekatan kuantitatif, seperti yang telah dijelaskan oleh Arikunto (2002) bahwa penelitian kuantitatif adalah penelitian yang banyak menggunakan angka-angka, mulai dari pengumpulan data, penafsiran terhadap data serta penampilan dari hasilnya. Variabel penelitian adalah suatu atribut atau sifat-sifat atau nilai dari seseorang, objek, atau kegiatan yang mempunyai variasi tertentu yang ditetapkan oleh peneliti untuk dipelajari dan ditarik kesimpulannya (Sugiono, 2004). Dalam penelitian ini, variabel yang digunakan adalah: a) servant leadership sebagai variabel bebas (X) dan b) komitmen organisasi sebagai variabel terikat $(\mathrm{Y})$.

\section{Sampel}

Menurut Winarsunu (2004) sampel adalah sebagian kelompok individu yang dijadikan wakil dalam penelitian. Sedangkan menurut Sutrisno (2001) sampel merupakan bagian atau representasi dari populasi yang akan diteliti.Adapun dalam penelitian ini populasi yang digunakan adalah karyawan dari RSDS yang berjumlah 386 karyawan.Pengambilan sampel pada penelitian ini menggunakan teknik purposive sampling, yaitu teknik penentuan sampel dengan pertimbangan tertentu (Sugiyono, 2000).Sampel dalam penelitian ini adalah pimpinan pada RSDS baik dari tingkat direksi maupun manajerial. Ciri-ciri sampel 
penelitian adalah sebagai berikut: (1) Usia minimal 30 tahun; (2) Pendidikan minimal D III; (3) Telah bekerja minimal 2 tahun di RSDS; dan (4) Memiliki bawahan atau anggota karyawan.

\section{Teknik Pengumpulan Data}

Data dikumpulkan menggunakan instrumen skala likert servant leadership dan komitmen organisasi yang mempunyai empat pilihan jawaban, yakni Sangat Setuju, Setuju, Tidak Setuju, Sangat Tidak Setuju. Penskalaan metode likert ini merupakan metode penskalaan pernyataan sikap yang menggunakan distribusi respon dasar penentuan nilai skalanya.

Pengukuran konstruk servant leadership digunakan skala likert yang dikembangkan dari hasil penelitian Barbuto dan Wheeler dalam Handoyo (2010) skala ini terdiri dari 39 item

Komitmen Organisasi dalam penelitian ini diungkap menggunakan skala komitmen organisasi yang disusun berdasarkan pada teori Meyer, danAllen dalam Sopiah (2008).

Tabel 1. Deskripsi Nilai Dan Kebutuhan

\begin{tabular}{|c|c|c|c|}
\hline No & Dimensi & Aitem & Jumlah \\
\hline 1. & Altruistic calling & $2,5,27,31,38$ & 5 \\
\hline 2. & $\begin{array}{l}\text { Emotional } \\
\text { Healing }\end{array}$ & $7,9,17,32$ & 4 \\
\hline 3. & Wisdom & $1,3,14,21$ & 4 \\
\hline & $\begin{array}{l}\text { Persuasive } \\
\text { Mapping }\end{array}$ & $8,22,24,25,34$ & 5 \\
\hline & $\begin{array}{l}\text { Organizational } \\
\text { Stewardship }\end{array}$ & $10,18,28,29,35$ & 5 \\
\hline & Humility & $13,19,23,33,36,3,9$ & 6 \\
\hline & Vision & $4,15,16,20,26$ & 5 \\
\hline \multirow{2}{*}{\multicolumn{2}{|c|}{ 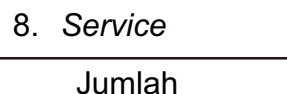 }} & $6,11,12,30,37$ & 5 \\
\hline & & & 39 \\
\hline
\end{tabular}

\section{Teknik Analisis Data}

Sebelum dilakukan perhitungan dengan menggunakan teknik korelasi, terlebih dahulu diadakan uji asumsi yaitu uji normalitas dan
Tabel 2. Blue Print Skala Komitmen Organisasi

\begin{tabular}{|c|c|c|c|}
\hline \multirow[b]{2}{*}{ Dimensi } & \multicolumn{2}{|c|}{ Aitem } & \multirow{2}{*}{$\begin{array}{l}\text { Jum } \\
\text { lah }\end{array}$} \\
\hline & $\begin{array}{c}\text { Favour } \\
\text { able }\end{array}$ & $\begin{array}{c}\text { Jnfavour } \\
\text { able }\end{array}$ & \\
\hline 1. Affective Commitment & $1,2,3$ & 4,5 & 5 \\
\hline 2. Continuance Commitment & $\begin{array}{l}6,8 \\
9,10\end{array}$ & 7 & 5 \\
\hline 3. Normative Commitment & $\begin{array}{l}11,13, \\
14,15\end{array}$ & 12 & 5 \\
\hline Jumlah & & & 15 \\
\hline
\end{tabular}

uji linieritas. Uji normalitas dilakukan untuk mengetahui normalitas distribusi.Penyebaran data hasil pengumpulan skala dapat mengetahui distribusi normal atau tidak normal.Untuk menguji normalitas data peneliti menggunakan kolmogrov smirnov test. Uji kolmogrov smirnov test merupakan uji normalitas yang sering dipakai. Adapun syarat suatu data dapat dikatakan berdistribusi normal adalah signifikansi atau nilai probabilitasnya lebih dari 0,05 (Sugiyono, 2009).

Uji linieritas dibutuhkan untuk penelitian korelasi.Uji linieritas adalah suatu prosedur yang digunakan untuk mengetahui status linier.Uji ini biasanya digunakan sebagai prasyarat dalam analisis korelasi. Pengujian pada SPSS (Statistical product and service) dengan menggunakan test for linearity dengan pada taraf signifikansi 0,05 (Sugiyono, 2000).

Teknik analisa data yang digunakan adalah analisa korelasi product moment (korelasi pearson) adalah teknik yang analisis statistik parametrik inferensial yang mempunyai kegunaan untuk menganalisis data penelitian. Data yang telah diperoleh akan dianalisis dengan menggunakan uji statistik korelasi product moment dari carl pearson dengan bantuan SPSS (Statistical product and service) versi 17.0 for windows yang mempunyai karakteristik di antaranya: a) hipotesis yang diajukan adalah hipotesis asosiatif; b) datanya berskala minimal interval; dan c) penyebaran data berdistribusi 
normal.

\section{HASIL DAN PEMBAHASAN}

\section{Hasil}

Adapun hasil uji normalitas (kolmogrov -smirnov) untuk variabel servant leadership dan komitmen organisasi adalah sebagai berikut:

Tabel 1. Deskripsi Nilai Dan Kebutuhan

\begin{tabular}{ccc}
\hline Variabel & Nilai P (sig) & Keterangan \\
\hline $\begin{array}{c}\text { Servant } \\
\text { Leadership }\end{array}$ & $\begin{array}{c}0.454 \\
(p>0,05)\end{array}$ & $\begin{array}{c}\text { Distribusi } \\
\text { data normal }\end{array}$ \\
Komitmen & 0.359 & $\begin{array}{c}\text { Distribusi } \\
\text { Organisasi }\end{array}$ \\
$(p>0,05)$ & data normal \\
\hline
\end{tabular}

Berdasarkan hasil uji normalitas menggunakan kolmogrov-smirnov diketahui bahwa nilai $\mathrm{p}$ variabel servant leadership adalah 0.454 dan nilai $p$ komitmen organisasi adalah 0.359. Hal ini menunjukkan bahwa distribusi data kedua variabel tersebut termasuk data yang berdistribusi normal karena memiliki nilai signifikansi $>0,05$.

Adapun hasil uji linieritas kedua variabel data penelitian adalah sebagai berikut:

Tabel 1. Deskripsi Nilai Dan Kebutuhan

\begin{tabular}{ccc}
\hline Variabel & Linieritas & Keterangan \\
\hline Servant Leadership & $0.933(\mathrm{p}>$ & Distribusi data \\
Komitmen Organisasi & $0,05)$ & linier \\
\hline
\end{tabular}

Berdasarkan tabel tersebut menunjukkan hubungan antara varaiabel servant leadership dengan komitmen organisasi memiliki nilai $p=0.933$ berarti $p>0,05$. Hal ini menunjukkan bahwa variabel servant leadership di dalam penelitian ini berhubungan secara linier dengan komitmen organisasi.Berdasarkan hasil pengolahan data dengan analisis korelasi product moment dengan bantuan SPSS 17.0 statistic for windows maka didapatkan hasil sebagai berikut :
Tabel 1. Deskripsi Nilai Dan Kebutuhan

\begin{tabular}{cccc}
\hline Variabel & $\mathbf{r}$ & Sig $(\mathbf{p})$ & Keterangan \\
\hline $\begin{array}{c}\text { Servant } \\
\text { Leadership }\end{array}$ & 0.617 & 0.004 & $\begin{array}{c}\text { Koefisien } \\
\text { korelasi } \\
\text { Komitmen } \\
\text { Signifikan }\end{array}$ \\
\hline Organisasi & & & \\
\hline
\end{tabular}

Berdasarkan tabel diatas dapat diketahui bahwa variabel servant leadership memiliki hubungan yang signifikan terhadap komitmen organisasi karena mempunyai nilai signifikansi kurang dari 0,05 $(\mathrm{p}<0,05)$ dan koefisien korelasinya sebesar $\mathrm{r}=0,617$. Dengan hasil yang demikian, berarti hipotesis yang diajukan dalam penelitian ini diterima dengan hasil yang didapatkan karena terdapat hubungan antara tingkat servant leaderhsip dengan tingkat komitmenorganisasi pada karyawan Rumah Sakit Delta Surya Sidoarjo

\section{Pembahasan}

Berdasarkan analisis data yang dilakukan dengan menggunakan korelasi product moment, diketahui bahwa ada hubungan yang signifikan antara servant leadership dengan komitmen organisasi pada karyawan Rumah Sakit Delta Surya Sidoarjo. Dengan hasil demikian, hipotesis yang diajukan dalam penelitian ini diterima karena sesuai dengan hasil penelitian yaitu terdapat hubungan yang signifikan antara tingkat servant leadership dengan komitmen organisasi pada karyawan Rumah Sakit Delta Surya Sidoarjo.

Hasil tersebut sesuai dengan yang dikatakan Lantu (2007) bahwa Servant leadership yang baik berarti bahwa karyawan memiliki pemahaman bahwa pemimpin tersebut akan menempatkan kebutuhan pengikut sebagai prioritas utama dan memperlakukan bawahan atau anggota sebagai rekan kerja serta memandang bahwa tujuan organisasi hanya akan dapat dicapai dalam basis pengembangan jangka panjang, yaitu dengan cara memfasilitasi pertumbuhan, 
pengembangan, dan kesejahteraan individuindividu yang menjadi anggota perusahaan.

Sejalan dengan itu, Lantu (2007) juga mengungkapkan fokus utama dalam servant leadership adalah pada bagaimana mengembangkan pihak lain (pengikut, komunitas internal dan eksternal), bukan untuk mementingkan diri sendiri.Pemenuhan kepentingan diri sendiri bukanlah hal yang dicari oleh seorang servant leadership, tetapi lebih pada peningkatan motivasi yang lebih tinggi. Jadi, tujuan utama seorang servant leadership adalah bukan untuk mengejar banyaknya profit yang dihasilkan dalam setiap tahunnya, tetapi lebih pada bagaimana menumbuhkembangkan komunitas, baik bagi mereka yang ada dalam perusahaan, maupun masyarakat yang berada disekitar tempat perusahaan tersebut beroperasi.

Lantu (2007) juga menjelaskan tingkat servant leadership dapat dikembangkan dengan memberikan pemahaman yang mendalam mengenai melayani pihak lain dengan melakukan pendekatan secara menyeluruh pada pekerjaan, komunitas, serta proses pengambilan keputusan yang melibatkan semua pihak. Tindakan pemimpin yang secara terus-menerus mengembangkan karyawan (anggota organisasi) akan mengarahkan pada terciptanya kepuasan kerja dan meningkatnya komitmen karyawan terhadap perusahaan dan pekerjaannya secara signifikan. Pengembangan karyawan juga akan memberikan pengaruh positif pada peningkatan produktivitas kerja karyawan, yang selanjutnya berakibat pada naiknya kinerja atau performansi.

Sementara itu Sopiah (2008) menjelaskan bahwa komitmen organisasi yang baik berarti bahwa karyawan memiliki pemahaman tentang pekerjaan yang dijalaninya serta kesediaan untuk menjadi sebaik mungkin demi kepentingan organisasi tersebut dan kepercayaan dan penerimaan yang kuat terhadap nilai - nilai dan tujuan organisasi.
Sejalan dengan itu, Sopiah (2008) juga menjelaskan bahwa komitmen organisasi merupakan salah satu sikap yang merefleksikan perasaan suka atau tidak suka terhadap organisasi pada tempat bekerja, komitmen organisasi merupakan suatu keadaan atau derajat sejauh mana seorang karyawan memihak pada suatu organisasi tertentu dan tujuan-tujuannya, serta berniat memelihara keanggotaan dalam organisasi itu. Konstruksi dari komitmen organisasi memusatkan perhatian kepada kesetiaan karyawan terhadap organisasi.Ini merupakan kondisi psikologi atau orientasi karyawan terhadap organisasi dimana karyawan bersedia mengeluarkan energi ekstra demi kepentingan perusahaan.

Hasil penelitian ini didukung oleh Tanajaya dan Nugroho (1995) mengatakan bahwa hadirnya komitmen dalam diri karyawan akan memberikan keuntungan bagi organisasi, seperti mendapat dukungan optimal dari para karyawan dan mengurangi ongkos dalam pemeliharaan SDM. Karyawan yang memiliki komitmen tinggi akan memandang pekerjaan bukan sebagai beban atau kewajiban tetapi sarana berkarya dan mengembangkan diri, karena seseorang karyawan diharapkan mampu menjiwai pekerjaannya serta bekerja dengan pikiran dan hati.

Beberapa perilaku individu dalam organisasi terjadi karena adanya dukungan dan kerjasama antara pimpinan dan karyawannya dimana individu mengambil sikap dan tindakan dalam organisasi dengan pertimbangan tertentu. Seorang pemimpin di perusahaan dalam situasi perubahan organisasi dituntut untuk mampu mempersiapkan perusahaannya untuk berkembang secara positif bagi masyarakat dan secara internal mendorong perusahaan menjadi komunitas, tidak sekedar kumpulan orang yang sedang bekerja. Karyawan yang bekerja dalam perusahaan ini juga akan merasa 
kemampuan mereka diperdayaguna-kan dan memiliki perasaan keterikatan yang tinggi pada perusahaan, dia akan merasa menjadi bagian dari perusahaan dan memilih bertahan diperusahaan jika perusahaan mendapat masalah. Karyawan juga akan menunjukkan kinerja terbaiknya untuk perusahaan, dia juga akan menjalankan perannya dengan baik, mengerjakan tugas dengan baik, dia juga akan mendukung kebijakan perusahaan, mendukung kepentingan perusahaan daripada kepentingan pribadi termasuk juga membantu rekan kerja yang kesulitan dalam mengerjakan pekerjaannya, melakukan inovasi-inovasi untuk kemajuan perusahaan dan sebagainya. Perilaku seperti inilah yang menggambarkan komitmen organisasi.

Berdasarkan uraian diatas dapat dikatakan bahwa servant leadership berhubungan dengan komitmen organisasi. Karena secara langsung maupun tidak langsung servant leadership yang dimiliki oleh individu dalam perusahaannya akan mendorong komitmen organisasi dimanapun individu berada.

Pada hasil diatas, dapat disimpulkan bahwa karyawan Rumah Sakit Delta Surya Sidoarjo telah mencapai tingkat servant leadership dan komitmen organisasi cukup baik. Selain faktor servant leadership, dimungkinkan terdapat faktor-faktor lain yang mempengaruhi tingkat komitmen organisasi karyawan. Hal tersebut disebabkan karyawan sebagai individu yang terdiri dari berbagai aspek, baik fisik maupun psikis memerlukan dari faktor dalam diri maupun luar dirinya yang akan mampu meningkatkan kualitas karyawannya.

\section{Simpulan dan Saran}

Dari hasil penelitian yang telah dilakukan dapat diambil kesimpulan mengenai hubungan antara servant leadership dengan komitmen organisasi pada karyawan Rumah Sakit Delta Surya Sidoarjo. Hubungan antara servant leadership dengan komitmen organisasi pada karyawan Rumah Sakit Delta Surya Sidoarjo menunjukkan hasil korelasi variabel servant leadership dan komitmen organisasi yang berarti bahwa hipotesis yang diajukan diterima, yaitu terdapat hubungan antara kedua variabel tersebut.

Sehubungan dengan hasil penelitian ini, terdapat beberapa saran yang ingin disampaikan peneliti. Rumah sakit harus lebih memperhatikan kondisi karyawannya dengan cara memberikan training secara berkala, pemahaman, reward sehingga karyawan memiliki rasa kepemilikan terhadap perusahaan yang nantinya akan meningkatkan servant leadership dan komitmen organisasinya.

Para karyawan hendaknya meningkatkan servant leadership dan komitmen organisasi terhadap perusahaan karena tempat mereka bekerja adalah pelayanan kesehatan. Diharapkan dengan adanya servant leadership yang tinggi terhadap perusahaan akan memunculkan perilaku komitmen organisasi yang tinggi pula.

Peneliti selanjutnya dapat menambahkan variabel lain yang berhubungan dengan peran servant leadership dan komitmen organisasi. Penambahan atau perubahan pada variabel servant leadership dan komitmen organisasi diharapkan dapat menambah manfaat yang nantinya berguna untuk memperluas pengetahuan yang dimiliki.

\section{Daftar Pustaka}

Anderson, J. (2008). The Writing's of Robert K. Greenleaf: An interpretive analysis and the future of Servant Leadership. New York. Anonim(2008).Laporan PKPA RS Delta Surya
Sidoarjo, Program Profesi Apoteker, Fakultas Farmasi Universitas Airlangga, Surabaya. Anonim (2008).Profil RS Delta Surya, Sidoarjo. 
Arikunto, S. (2002). Prosedur Penelitian. Edisi revisi III. Jakarta: Rineka Cipta

Azwar, S. (2005). Penyusunan Skala Psikologi, Yogyakarta : Penerbit Pustaka Pelajar

Barbuto, J.E., \& Wheeler, D.W. (2006).Scale development and construct clarification of servant leadership, Group and Organization Management. New York

Bass , B. M. (2000). The future of leadership in learning organization.The Journal of leadership studies. New York

Fauzan \& Baihaqi. (2010). pengaruh gaya kepemimpinan terhadap kepuasan kerja dan kinerja dengan komitmen organisasi sebagai variabel intervening. Fakultas Ekonomi Universitas Diponegoro: Semarang

Fineman, S., Sims, D., \& Gabriel , Y. (2005). Organizing and Organization Understanding the Human Side of Work. Newyork: A Division Siroon and Schuster. Inc.

Graham, J.W. (1991). Servant leadership in organizations: Inspirational and moral. New York.

Greenleaf, R.K. (1996). Servant Leadership :A journey into the nature of servant leadership. New York

Hadi, S. (2004). Metodologi Research Edisi I, Yogyakarta: Penerbit yayasan Penerbitan Fakultas Psikologi Universitas Gadjah Mada.

Handoyo, S. (2010). Pengukuran Servant Leadership sebagai Alternatif Kepemimpinan di Institusi Pendidikan Tinggi pada Masa Perubahan Organisasi. Fakultas Psikologi Universitas Airlangga: Surabaya

Heristi \& Handoyo, S. (2011). Hubungan antara servant leadership dengan efektifitas tim ditinjau dari persepsi anggota tim PHKIJurusan di Institut Teknologi Sepuluh Nopember Surabaya. Fakultas Psikologi Universitas Airlangga: Surabaya

Indira, J., Bunyaanudin, A. (2006). Pengaruh
Komitmen Organisasi dan Keterlibatan Kerja Islam dengan Sikap Terhadap Perubahan Organisasi.

Lantu, D., Pesiwarissa, E., \& Rumahorbo, A. (2007).Servant Leadership. Yogyakarta: Gradien Books.

Laub, J. (2004). Defining Servant Leadership: A recommended Typology for Servant Leadership Study. Journal Servant Leadership Roundtable, Regent University, Virginia Beach, VA.

Luthans, F. (2007). Perilaku Organisasi. Yogyakarta: Andi.

Mathis, Robert. L \& Jackson, John. H. (2006). Manajemen Sumber Daya Manusia. Edisi kesepuluh.Jakarta : Penerbit Salemba Empat.

Rahmania,\& Handoyo. (2009). Hubungan antara Servant Leadership dengan Organizational Citizenship Behavioral pada Dosen Institut Teknologi Sepuluh Nopember Surabaya. Fakultas Psikologi Universitas Airlangga: Surabaya

Resi,\& Yudhaningsih. (2011). peningkatan efektifivitas kerja melalui komitmen, perubahan, dan budaya organisasi. Tujuan dari penelitian ini adalah untukmengetahui hubungan antara efektivitas kerja melalui komitmen, perubahan, dan budaya organisasi. Fakultas Ekonomi Universitas Diponegoro: Semarang

Robbins, S. (2002), Organizational Behavioredisi bahasa Indonesia, buku 1 dan 2, Penerbit Indeks, Jakarta.

Russel, S. (2002). A Review of Servant Leadership attributes: Developing a practical model. Leadership and organizational developmentjournal. New York.

Sopiah, (2008), perilaku organisasional, Penerbit Andi, Yogyakarta.

Sovya \& Desianty. (2005), pengaruh gaya kepemimpinan terhadap komitmen organisasi pada PT POS Indonesia (PERSERO) Semarang. Fakultas Ekonomi Universitas Diponegoro: Semarang 
Spears, L. (1995).Reflection on Leadership :Robert K. Greenleaf theory of Servant Leadership, New York

Sugiyono(2000).Metode Penelitian Kuantitatif dan Kualitatif.Alfabeta: Bandung

Tanajaya, M., Noegroho, S. (1995). Perbedaan faktor-faktor Keterikatan Kerja Karyawan Terhadap Organisasi Ditinjau Dari Jenis Kelamin.Jurnal Psikologi Indonesia Pusat.Jakarta
Temaluru J. (2001). Hubungan antara Komitmen terhadap Organisasi dan faktor-faktor Demografis dengan Kepuasan Kerja Karyawan.Pengembangan Kualitas Sumber Daya Manusia dari Perspektif Psikologi Industri Organisasi.Depok : Bagian PIO Fakultas Psikologi UI.

Winarsunu, Tulus. (2004). Statistik dalam Penelitian Psikologi dan Pendidikan. UMM Press. Malang 